\title{
Histological Architectures and Biometric Characteristics of Indigenously Plastinated Organs of Goat
}

\author{
Arquitectura Histológica y Características Biométricas \\ de Órganos de Cabra Plastinados Localmente
}

Rafiqul Islam; Ummay Ayman \& Nasrin Sultana

\begin{abstract}
ISLAM, R.; AYMAN, U. \& SULTANA, N. Histological architectures and biometric characteristics of indigenously plastinated organs of goat. Int. J. Morphol, 39(3):759-765, 2021.

SUMMARY: The histo-morphology and biometry of liver, lung and kidney of goat were studied. The obtained samples were divided into two groups. One set of tissue was processed for paraffin embedding after formalin fixation. The other set was indigenously plastinated. The plastinates were embedded with paraffin without deplastination. Both the non plastinated and plastinated tissues were sectioned and processed for routine staining. The tissues were examined under light microscope for histological architectures and quantitatively assessed the biometric parameters. The non plastinated and plastinated samples yielded mostly similar histological architectures. But plastinated liver showed alterations and artifacts with enlargement of the central vein and hepatic sinusoidal space. Plastinated lung revealed enlarged alveolar sac. Lack of nuclear clarity was observed for all the plastinated samples. The plastinated kidney revealed compactness of the cellular structures and shrinkage induced artifacts with clear renal corpuscles structure and obvious glomerular capsule (Bowman's capsule). The biometric measurements of central vein of liver, alveolar sac of lung, glomerulus and glomerular space of kidney of both plastinated and non plastinated tissue were also performed using calibrated stage micrometer. Comparison was done between the biometric data for both plastinated and non plastinated tissue. No significant difference was found in the obtained biometric data of liver and lung. Only a significant difference was observed between the width of glomerulus of non plastinated kidney and width of glomerulus of plastinated kidney. The morphological and biometric study of non plastinated and plastinated organs of goat can conclude that histological slides can be made from indigenously plastinated organs with well preserved histological architectures of the tissues with some rare exceptions. Plastination does not affect the biometric characteristics of the organs. In addition, the comparative morphologic and biometric study of plastinated and non plastinated organs of goat will be useful in education and research.
\end{abstract}

KEY WORDS: Biometry; Goat; Histomorphology; Plastination.

\section{INTRODUCTION}

Plastination is a method of preserving the biological tissues with completely visible surface and prolonged durability. It is an alternative tissue preservation technique in which water and lipids are replaced by polymer (Ottone et al., 2018) resulting in dry, odorless and non toxic specimens of almost any animal tissues (Grondin et al., 1994). Despite the fact that the process is tedious, it is valuable, particularly in preserving rare specimens since the plastinates keep going forever without the requirement for preservatives (von Hagens, 1986). It also enables explorative learning for non dissection based courses (Suganthy \& Francis, 2012). The visceral organs (those of the digestive, respiratory, urinary, genital, cardiovascular, and nervous systems) of goat were impregnated by paraffin which retained their original shape without losing any aspects of their physical appearance, such as color, following the impregnation process (Sultana et al., 2019). This process is gaining attention for its advantages as an educational and research tool. Because of these properties, analysts have been attempting to expand its extension in different educational and research purposes (Steinke et al., 2008).

Due to our involvement in this procedure for the last few years, we frequently considered what the results would be of histological investigations of plastinated tissues after a certain time period. One of the most significant and conceivably helpful characteristics of tissue plastination by silicone is that the microscopic structure stays intact and 
can be preserved for almost indefinite period (Ravi \& Bhat, 2011). The microscopic appearances were not always identical but diagnostic pathologic features were readily discernable in the deplastinated tissue (Walker et al., 1988). The histological architecture of the deplastinated tissue was maintained and was comparable with routine paraffin sections along with clearly visible intracellular structures like nuclei, nucleoli, fat droplets (Francis \& Rabi, 2017). The spleen, liver and kidney tissue sections of pig were studied histologically before and after indigenous plastination which revealed an excellent maintenance of tissues morphology in light microscopic study (Manjunatha et al., 2014). On another study, light microscopic study of pig kidney samples without de-plastination showed a well preserved histological structure of tubules and renal corpuscles (Ramos et al., 2018).

According to the findings of Klaus et al. (2017), plastinates at present don't permit further analyzation or histology based studies which forestalls its utilization for research purposes. Plastinated specimens embedded in paraffin cannot always be used for microscopy because of artifacts produced during cutting (Grondin et al.). But the ultimate fate of paraffin embedded plastinated tissues for histological study after a definite time period is still ambiguous. Therefore, the present study was carried out to compare the histological architectures and biometric characteristics of non plastinated and plastinated tissues i.e. liver, lung and kidney of goat.

\section{MATERIAL AND METHOD}

Ethical approval: The study was solely conducted in the Department of Anatomy and Histology, Faculty of Veterinary Science, Bangladesh Agricultural University, Bangladesh. Ethical clearance of the present study and all experimental procedures was obtained from the guidelines for the care and use of animals by Animal welfare and Experimentation Ethics Committee, Bangladesh Agricultural University, Bangladesh [AWEEC/BAU/ 2019(27)].

Animals and Specimens: The tissue samples i.e. liver, lungs and kidney were collected from Black Bengal goat immediately after slaughtering. The goat had no developmental disorders and detectable diseases that may cause any drawback to study the histo-morphometry and biometry of the collected tissues. For dissecting the animals, a median incision was made from the mandibular space (between the rami of the mandible) to the anus. The body trunks were opened to show the splanchnics in situ.
Then, the organs were collected and washed carefully with phosphate-buffered saline. Then the obtained samples were divided into two groups. One set of tissue was processed for paraffin embedding after $10 \%$ formalin fixation. The other set was plastinated ( preserved in $20 \%$ formalin, hardened in a deep freeze, dehydrated and dried in freeze dryer, impregnated with melted paraffin, cured and stored in air tight container at room temperature). Then, all the samples were studied for histomorphology and biometry. The plastination process is described by Sultana et al.

Histo-morphometric study: For histological investigations, the non plastinated tissues were fixed in the $10 \%$ formalin for 72 hours and dehydrated by passing through ascending graded of alcohol followed by clearing in xylene. The tissues were then infiltrated with different grades of melted paraffin $\left(49^{\circ} \mathrm{C}, 55^{\circ} \mathrm{C}\right.$ and $\left.58^{\circ} \mathrm{C}\right)$ at 30 minutes interval in the oven and embedded with melted paraffin $\left(58^{\circ} \mathrm{C}\right)$. The plastinated tissue samples were embedded with melted paraffin without deplastination or any other further treatment. Afterwards, 5-6 $\mu \mathrm{m}$ (micrometer) thick sections were cut from the pastinated and non plastinated tissues using sliding microtome (MIC 509, Euromex, Japan) and stretched by floating on lukewarm water at $37^{\circ} \mathrm{C}$. Then the sections were mounted on adhesive painted glass slides and dried on slide warmer at $37^{\circ} \mathrm{C}$. Finally, the sections were processed and stained with Mayer's Hematoxylin and Eosin (H \& E) for histomorphometric and biometric analyses.

Photomicrographs and biometric measurements: The histological structures of both the plastinated and non plastinated tissues (liver, lung and kidney) were examined using light microscope under low (10X) and high (40X) magnifications. The necessary photographs were taken from the selected specimens using a digital camera for better illustration of the obtained results. Then the biometric measurements of different histological structures of the tissues were performed using calibrated stage micrometer in $\mu \mathrm{m}$ (micrometer). A total of thirty sections (five from each tissue) were biometrically evaluated. The biometric parameters i.e. length and width of the central vein of liver, length and width of alveolar sac of lungs, length and width of glomerulus of kidney and length of glomerular space of kidney were measured as part of biometric study.

Statistical analyses: All the biometric data obtained from the present study was compared by performing paired sample t-test using SPSS software (IBM SPSS Statistics 22). In all trials, data were expressed as mean \pm standard error of mean (SEM). Significant differences among the means were determined by using Duncan's multiple-range test at $\mathrm{P} \leq 0.05$. 


\section{RESULTS}

The non-plastinated and plastinated tissue sections of liver, lungs and kidney of goat yielded themselves to staining with routine haematoxylin and eosin verily well. Through light microscopic examination of both nonplastinated and plastinated specimens of liver, lungs and kidney, different histomorphometric and biometric findings were made for each organ.

Histological architectures of non plastinated and plastinated liver, lungs and kidney: The histo-architecture of non-plastinated liver revealed that the hepatic lobule was roughly hexagonal in shape with centrally located central vein.T he hepatocytes were found polygonal in shape with small nuclei. Hepatic sinusoids were present among radiating cords of liver cells. Connective tissue septum between portal triad in liver was merged with hepatic lobule. Branches of portal vein, hepatic artery and bile duct were present in the portal triad (Fig. 1). By contrast, the light microscopy of the plastinated liver sample of goat showed alterations and artifacts in comparison to the paraffin embedded liver sample. Central veins were found to be enlarged with the remarkable distention of the sinusoidal space. The cytoplasms of hepatocytes were remained intact but nuclear clarity was lost. Some artifacts were noticed in the hepatic cord arrangements of liver (Fig. 1).

The non-plastinated lung sample showed general histological architectures. Parabronchi was present which was lined with cuboidal epithelium. The inner lining of each

\section{Non-plastinated}

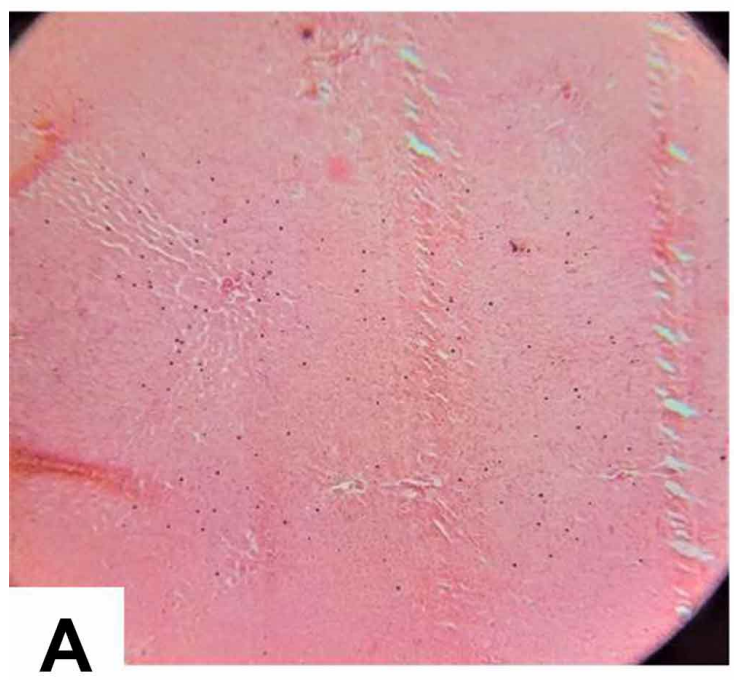

\section{Plastinated}
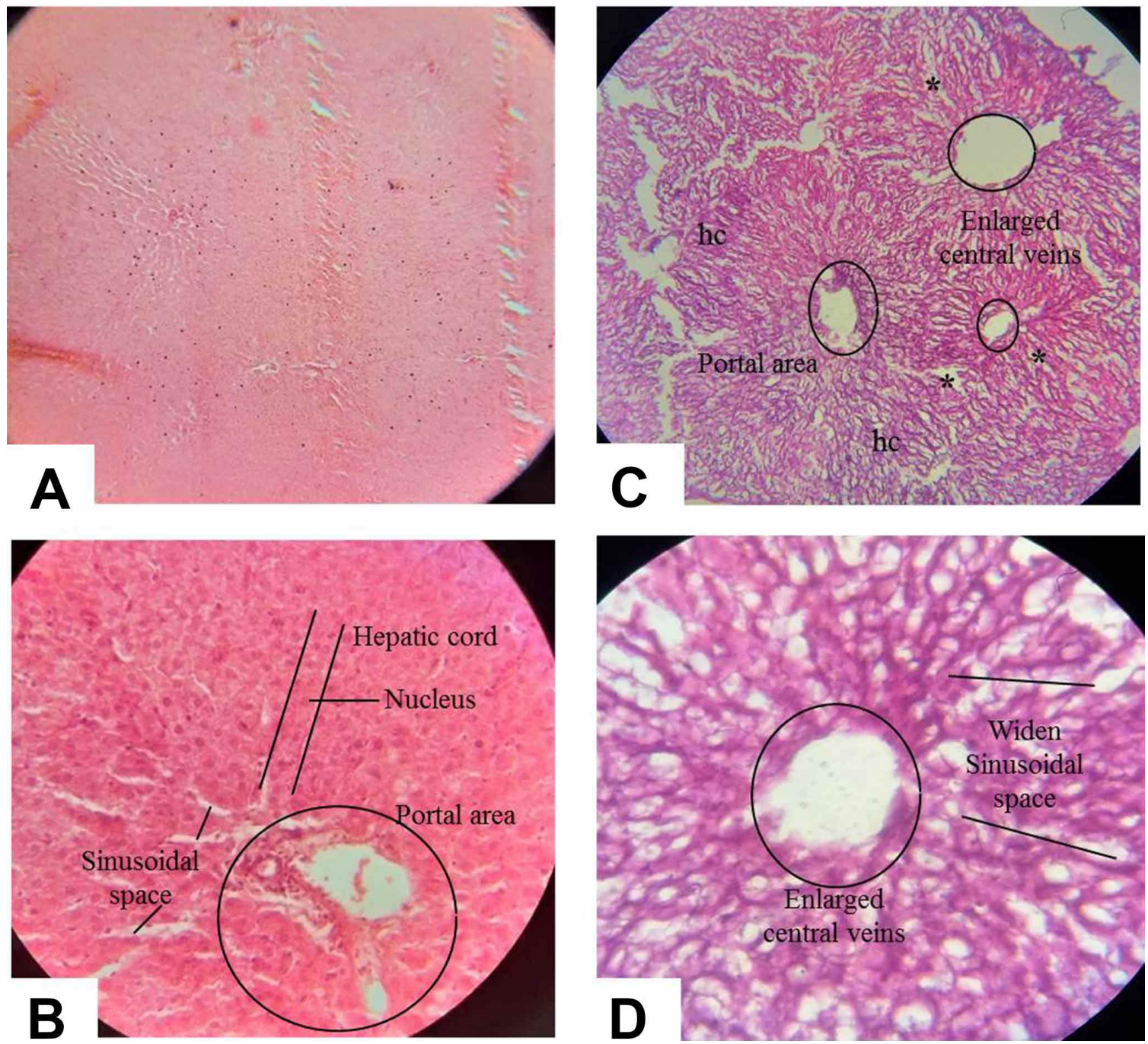

Fig. 1. Representative images of histological architectures of non-plastinated (A, B) and plastinated liver (C, D) of goat at 10X and 40X magnification. *-widen sinusoidal space, hc-irregular hepatic cords. 
parabronchi was connected with cavities called atrium or air vesicles. Blood capillary was noticed in the parenchyma (Fig. 2). On the other hand, all the above mentioned structures were present in the plastinated lung sample. Secondary bronchi were lined by columnar epithelium with a lamina propria layer and a well-developed muscularis was found (Fig. 2).

The non plastinated kidney sections showed good differential staining with clarity in both nuclear and cytoplasmic details. The parenchyma of kidney consisted of renal corpuscle and renal tubules. In renal corpuscle, glomerulus found to be surrounded by the double layers of Bawman's capsule; simple squamous epithelium of parietal layer was easily visible. The glomerular space was comparatively narrow and the epithelial lining of convoluted tubules and collecting ducts were distinct with cytoplasmic and nuclear clarity (Fig. 3). On the other side, The plastinated kidney sections revealed compactness of the cellular structures with shrinkage induced artifacts. But the renal corpuscles structure remained clearly visible with obvious glomerular capsule and its parietal layer of simple squamous epithelium followed by wider glomerular space (Bowman space) as compared to the non-plastinated kidney. There was a compact arrangement of glomerular tufts and macula densa at urinary pole of plastinated kidney. The convoluted tubules were distorted and lack of cytoplasmic and nuclear clarity was noticed (Fig. 3).

\section{Non-plastinated}
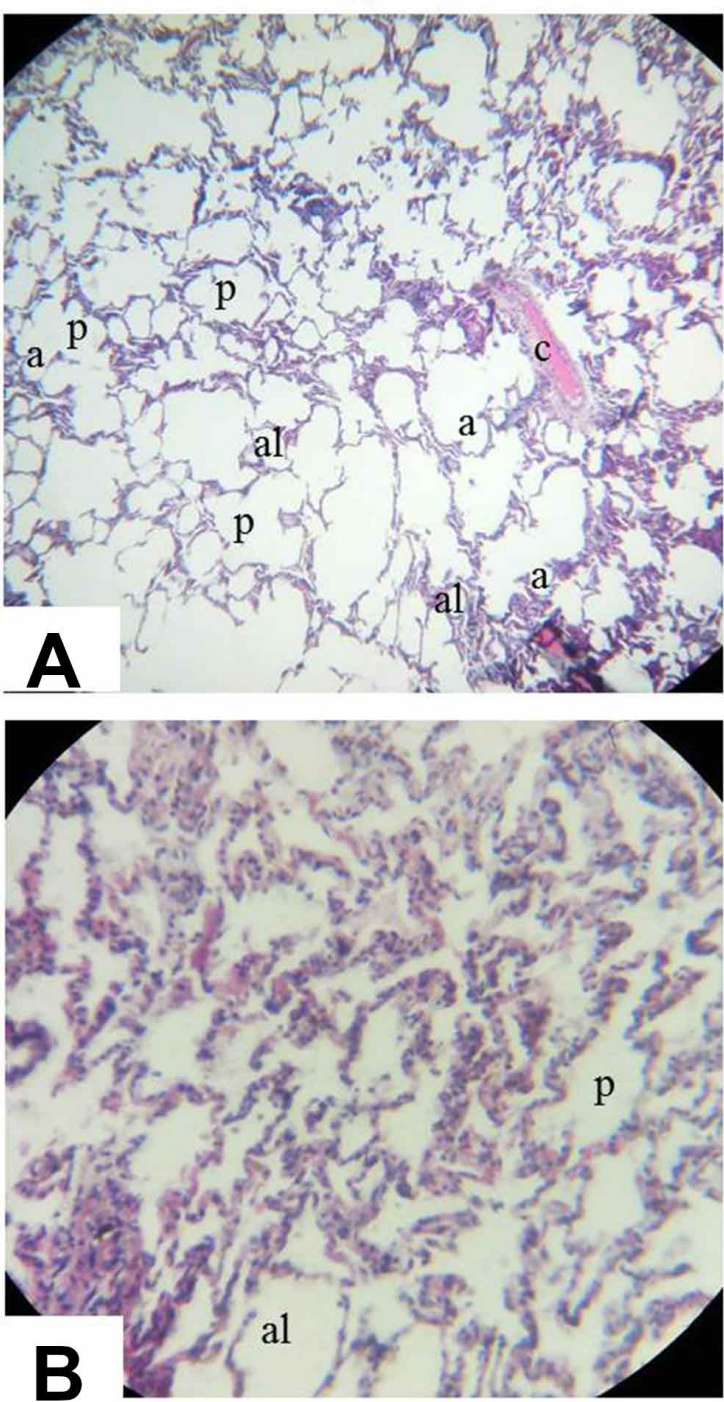

\section{Plastinated}
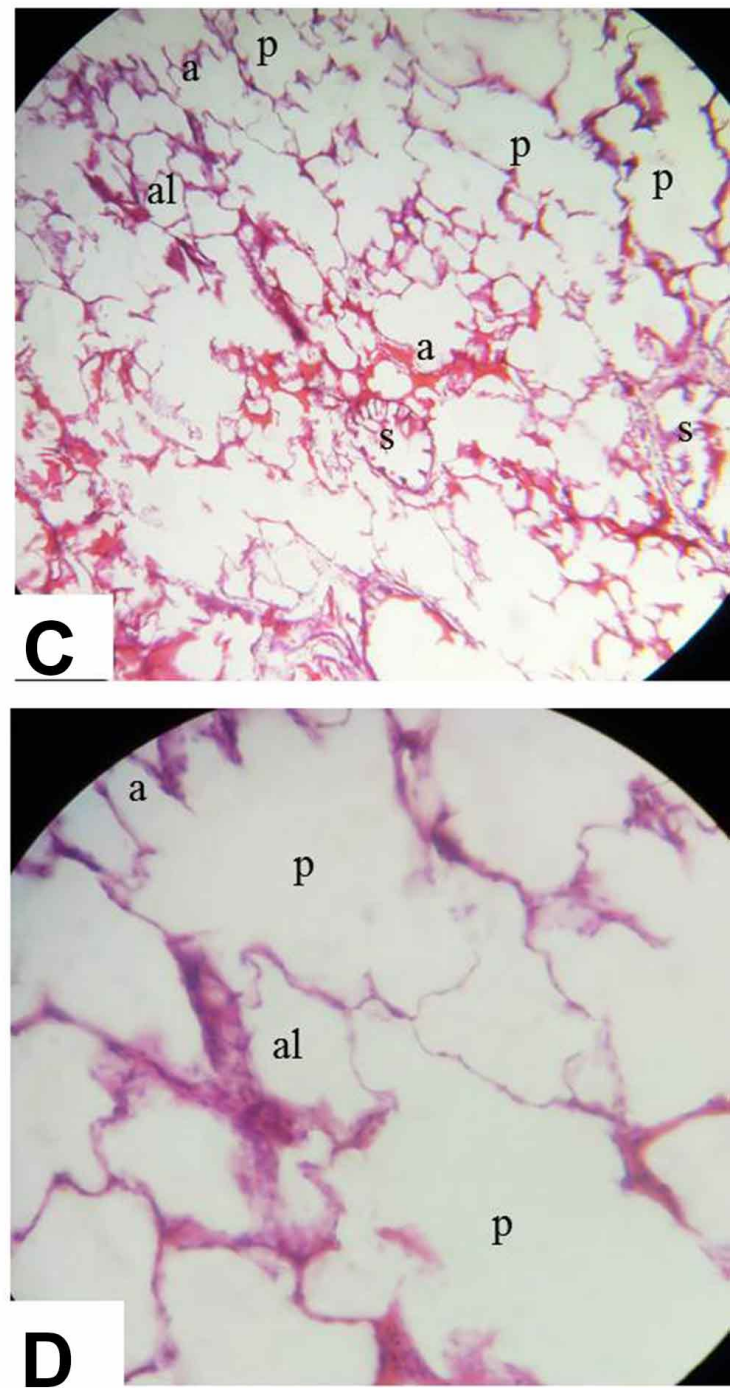

Fig. 2. Representative images of histological architectures of non-plastinated (A, B) and plastinated lungs (C, D) of goat at 10X and 40X magnification. a-atrium, c-blood capillary, p-parabronchi, s- secondary bronchi, al-alveoli. 
Biometry of non plastinated and plastinated liver, lungs and kidney: In the current study, data obtained from the biometric study of non plastinated and plastinated liver, lungs and kidney of goat were presented in Table I. The mean values obtained from the biometric parameters i.e. length and width of central vein of non plastinated and plastinated liver were not statistically significant. Similarly, the mean values of the biometric parameters i.e. length and width of alveolar sac of non plastinated and plastinated lung were found statistically non-significant. In non plastinated and plastinated kidney, the glomerular space length was not statistically significant. All these differences between the biometric parameters of different non plastinated and plastinated organs were statistically non significant. The only statistically significant $(\mathrm{P}<0.05)$ difference was found between the width of glomerulus in non plastinated and plastinated kidney which was $(132.92 \pm 4.35 \mu \mathrm{m})$ and $(89.42 \pm 2.42 \mu \mathrm{m}$ ) respectively (Table I).
Table I. Biometric parameters of different organs and their difference between the non plastinated and plastinated organs of goat.

\begin{tabular}{lcc}
\multicolumn{1}{c}{ Organs } & Biometric parameters & Mean \pm SEM \\
\hline NP liver & Length of central vein & $101.54 \pm 39.97$ \\
P liver & & $134.12 \pm 35.58$ \\
NP liver & Width of central vein & $64.04 \pm 16.92$ \\
P liver & & $92.64 \pm 24.58$ \\
NP lungs & Length of alveolar sac & $89.41 \pm 3.69$ \\
P lungs & & $124.85 \pm 12.03$ \\
NP lungs & Width of alveolar sac & $45.11 \pm 4.90$ \\
P lungs & & $56.39 \pm 3.51$ \\
NP kidney & Length of glomerulus & $78.14 \pm 4.84$ \\
P kidney & & $100.29 \pm 6.04$ \\
NP kidney & Width of glomerulus & $89.42 \pm 2.42$ \\
P kidney & & $132.92 \pm 4.36$ \\
NP kidney & Glomerular space & $19.33 \pm 1.39$ \\
P kidney & & $32.63 \pm 7.25$ \\
\hline
\end{tabular}

*Significance of the difference in mean between the two groups as assessed by paired sample t-test using SPSS software (IBM SPSS Statistics 22). Data are expressed as mean \pm standard error of mean (SEM). Significant differences among the means were determined by using Duncan's multiple-range test at $\mathrm{P} \leq 0.05$.NPNon plastinated, P- Plastinated.
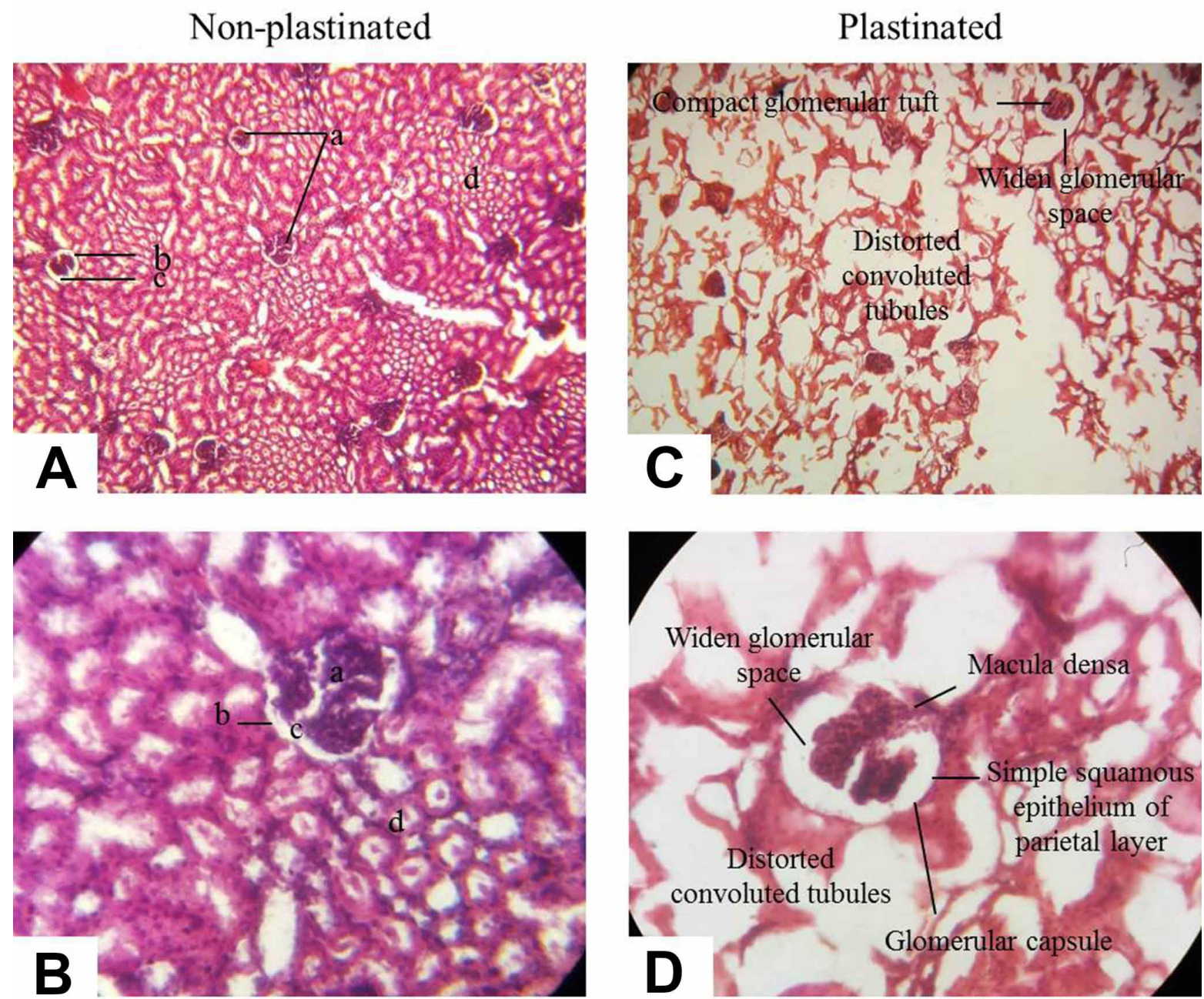

Fig. 3. Representative images of histological architectures of non-plastinated (A, B) and plastinated kidney (C, D) of goat at 10X and 40X magnification. a-glomerular tuft, b-glomerular capsule, c-glomerular space, d-convoluted tubules. 


\section{DISCUSSION}

Plastination has been an extraordinary tool in the armamentarium of an anatomist, which helps in the long haul protection of specimens without the requirement for preservatives. When used for educational purpose, the plastinates can be accessed at any time and allow the easy transportation of specimens to distant teaching sites outside the dissection hall without the need for carrying them in preservative laden containers (Rahul et al., 2020). Plastination likewise enables the students, academics and researchers to study an organ or tissue without being obliged by an actual division among himself and the specimen, that is, a container or gloves (Latorre et al., 2016; Klaus et al.; Rahul et al.). In the present study, we analyzed the histomorphology and biometry of different organs i.e. liver, lungs and kidney of goat by light microscopy of the tissues those were preserved after plastination.

Histological architectures of non plastinated and plastinated liver, lungs and kidney: A group of scientists used a control (non-plastinated tissue) to compare and validate the different methods used to process the plastinated tissue samples (Gartner \& Hiatt, 2003; Junqueira \& Carneiro, 2008; Ross \& Pawlina, 2008). The results we report here from cured plastinated samples, showed no disruption of the tissue histological and morphological characteristics. The sections of liver obtained by routine paraffin embedding technique revealed a very good differential staining and well preserved cellular structural details without any alteration or shrinkage induced artifacts. But the light microscopy of the plastinated liver sample of goat showed alterations and artifacts in comparison to the paraffin embedded liver sample which mismatches the findings of Manjunatha et al. The cytoplasms of hepatocytes were remained intact but nuclear clarity was lost. Losing of nuclear clarity may be due to the plastination process changing the electro negativity of the nucleus, and the basophilic pattern.

The non plastinated lung sections yielded staining verily well with excellent maintenance of cellular structures of the tissue. The plastinated lung sections contained similar histological structures (alveoli, alveolar sac, secondary bronchia, parabronchi) those are found in non plastinated lung sample. A loss of the volume of the epithelium of the bronchi was also observed which matches the findings of Ripani et al. (1996).

The non plastinated kidney sections yielded very good staining with clarity in both the cytoplasmic and nuclear details and distinctive cell boundary. Whereas, the plastinated kidney sections revealed compactness of the cellular structures with shrinkage induced artifacts which differs from the findings of Manjunatha et al. But the renal corpuscles structure remained clearly visible with obvious glomerular capsule and its parietal layer of simple squamous epithelium followed by wider glomerular space as compared to the non-plastinated kidney. There was a compact arrangement of glomerular tufts, macula densa at urinary pole of plastinated kidney and the convoluted tubules were distorted and lack of cytoplasmic and nuclear clarity was noticed which is similar to the findings of Manjunatha et al.

Biometry of non plastinated and plastinated liver, lungs and kidney: As far authors' knowledge, there is no published report on the biometric study of plastinated tissues. Central veins of the plastinated liver were found to be enlarged in comparison to the non plastinated liver. The sinusoidal space was also found distended remarkably. But all these differences were found statistically insignificant in biometric analysis. The mean values obtained from the biometric measurements of length and width of the plastinated and non plastinated lungs showed non significant difference. The biometric measurements of glomerulus of the plastinated and non plastinated kidney showed no significant difference. The glomerular space of both plastinated and non plastinated kidney also yielded non significant difference in biometric analyses. But significant difference was found between the mean values of the width of glomerulus in plastinated and non plastinated kidney $(\mathrm{P}<0.05)$.

In conclusion, the authors performed a novel study to explore the histological architectures and biochemical properties of indigenously plastinated organs of Black Bengal goat. The results obtained from the current study can conclude that histological slides can be made from the plastinated specimens embedding directly in paraffin without deplastination or any other further treatment. A plastinated sample doesn't prevent histological studies, within the above mentioned limits: loss of nuclear clarity, compactness or distension of cellular structures, shrinkage induced artifacts, slight distortions of the tubular structures, and interpretative caution. Further study is recommended to observe different time effects on the histomorphology of plastinated tissues.

\section{ACKNOWLEDGEMENTS}

The author's acknowledge the research assistance from the Department of Anatomy and Histology, Faculty of Veterinary Science, Bangladesh Agricultural University, Bangladesh. Dr. Nasrin Sultana is thankful to the Ministry of Science and Technology (BS-99/2019-20), Bangladesh for providing the research fund. 
ISLAM, R.; AYMAN, U. \& SULTANA, N. Arquitectura histológica y características biométricas de órganos de cabra plastinados localmente. Int. J. Morphol., 39(3):759-765, 2021.

RESUMEN: En este estudio se analizó la histomorfología y biometría de hígado, pulmón y riñón de cabra. Las muestras obtenidas se dividieron en dos grupos: una cohorte de tejido fue procesada para su inclusión en parafina después de la fijación con formalina. La siguiente cohorte fue plastinada localmente. Tanto los tejidos no plastinados como los plastinados fueron seccionados y procesados para tinción de rutina. Los tejidos se examinaron con un microscopio óptico en busca de arquitecturas histológicas y se evaluaron cuantitativamente los parámetros biométricos. Las muestras no plastinadas y plastinadas produjeron arquitecturas histológicas en su mayoría similares. El hígado plastinado mostró alteraciones y artefactos con un aumento de la vena central y del espacio sinusoidal hepático. El pulmón plastinado reveló aumento del saco alveolar. Se observó falta de claridad nuclear en todas las muestras plastinadas. El riñón plastinado reveló compacidad de las estructuras celulares y artefactos inducidos por contracción con estructura clara de corpúsculos renales y obvia cápsula glomerular (cápsula de Bowman). Las mediciones biométricas de la vena central del hígado, el saco alveolar del pulmón, el glomérulo y el espacio glomerular del riñón de tejido plastinado y no plastinado también se realizaron utilizando un micrómetro de platina calibrado. Se realizó una comparación entre los datos biométricos del tejido plastinado y no plastinado. No se encontraron diferencias significativas en los datos biométricos obtenidos de hígado y pulmón. Se observó una diferencia significativa entre el ancho del glomérulo del riñón no plastinado y el ancho del glomérulo del riñón plastinado. En el estudio morfológico y biométrico de órganos de cabra no plastinados y plastinados se puede concluir que es posible hacer portaobjetos histológicos a partir de órganos plastinados naturales con arquitecturas histológicas de los tejidos bien conservadas, con algunas excepciones. La plastinación no afecta las características biométricas de los órganos. Además, el estudio comparativo morfológico y biométrico de órganos plastinados y no plastinados de cabra será de utilidad en la educación y la investigación.

PALABRAS ClAVE: Biometría; Cabra; Histomorfología; Plastinación.

\section{REFERENCES}

Francis, D. V. \& Rabi, S. Deplastination: Making plastinates histopathologically relevant. J. Anat. Soc. India, 67(1):77-9, 2017.

Gartner, L. P. \& Hiatt, J. L. Tratado de Histologia em Cores. 2nd ed. Rio de Janeiro, Guanabara Koogan, 2003.

Grondin, G.; Grondin, G. G. \& Talbot, B. G. A study of criteria permitting the use of plastinated specimens for light and electron microscopy. Biotech. Histochem., 69(4):219-34, 1994.

Junqueira, L. C. \& Carneiro, J. Histologia Básica. $11^{\text {th }}$ ed. Rio de Janeiro, Guanabara Koogan, 2008.

Klaus, R. M.; Royer, D. F. \& Stabio, M. E. Use and perceptions of plastination among medical anatomy educators in the United States. Clin. Anat., 31(2):282-92, 2017.
Latorre, R.; Bainbridge, D.; Tavernor, A. \& López Albors, O. Plastination in anatomy learning: an experience at Cambridge University. J. Vet. Med. Educ., 43(3):226-34, 2016.

Manjunatha, K.; Prasad, R. V.; Jamuna, K. V.; Placid, E. S.; Suguna, R. \& Ramkrishna, V. Comparison of histological architecture of paraffin embedded and indigenously plastinated tissues. Indian J. Vet. Anat., 26(2):132-3, 2014.

Ottone, N. E.; Baptista, C. A. C.; Latorre, R.; Bianchi, H. F.; del Sol, M. \& Fuentes, R. E12 sheet plastination: Techniques and applications. Clin. Anat., 31(5):742-56, 2018.

Rahul, T. G.; Francis, D. V.; Pandit, S. \& Suganthy, J. Deplastination: preservation of histological structures and its anticipated role in the field of histopathology. Clin. Anat., 33(1):108-12, 2020.

Ramos, M. L.; De Paula, T. A. R.; Zerlotini, M. F.; Silva, V. H. D.; Carazo, L. B.; De Paula, M. F.; Silva, F. F. R.; Santana, M. L.; Silva, L. C. \& Ferreira, L. B. C. A comparison of different de-plastination methodologies for preparing histological sections of material plastinated with Biodur ${ }^{\circledR}$ S10 / S3. J. Plastination, 30(1):10-5, 2018.

Ravi, S. B. \& Bhat, V. M. Plastination: A novel, innovative teaching adjunct in oral pathology. J. Oral Maxillofac. Pathol., 15(2):133-7, 2011.

Ripani, M.; Boccia, L.; Cervone, R.; Macciucca, D. V. Light microscopy of plastined tissue, can plastinated organs be considered viable for structural observation. J. Int. Soc. Plast., 11:28-30, 1996.

Ross, M. H. \& Pawlina, W. Histologia: Texto e Atlas em Correlação com Biologia Celular e Molecular. $5^{\text {th }}$ ed. Rio de Janeiro, Guanabara Koogan, 2008.

Steinke, H.; Rabi, S.; Saito, T.; Sawutti, A.; Miyaki, T.; Itoh, M. \& SpanelBorowskia, K. Light-weight plastination. Ann. Anat., 190(5):428-31, 2008.

Suganthy, J. \& Francis, D. V. plastination using standard s10 techniqueOur experience in Christian Medical College, Vellore. J. Anat. Soc. India, 61(1):44-7, 2012.

Sultana, N.; Khan, M. Z. I.; Amin, T.; Jahan, M. R. \& Uddin, I. Preservation of internal organs of goat by an alternative method to plastination. $J$. Plastination, 31(1):14-8, 2019.

von Hagens, G. Heidelberg Plastination Folder: Collection of Technical Leaflets of Plastination. $2^{\text {nd }}$ ed. Heidelberg, Biodur products $\mathrm{GmbH}$, 1986.

Walker, A. N.; Jackson, R. L. \& Powel, S. Technical communication: Routine microscopy of deplastinated tissue. J. Int. Soc. Plastination, 2(1):40-2, 1988.

Corresponding author:

Dr. Nasrin Sultana

Associate Professor

Dept. of Anatomy and Histology

Bangladesh Agricultural University

Mymensingh

BANGLADESH

\section{E-mail: nsultana.bau@gmail.com/ nasrin.sultana@bau.edu.bd}

Received: 05-12-2020

Accepted: $30-01-2021$ 